\title{
Impementasi Peraturan Daerah No. 2 Tentang Penanggulangan Hewan Beresiko Rabies di Kabupaten Minahasa Tenggara
}

\author{
Audi Rondo \\ Universitas Negeri Manado
}

\begin{abstract}
Abstrak - Tujuan penelitian ini untuk mengetahui bagaimana
\end{abstract} (1)Implementasi Peraturan Daerah No.2 Tahun 2016 tentang Penanggulangan Hewan Beresiko Rabies khususnya hewan anjing di Kabupaten Minahasa Tenggara, (2) Faktor-faktor penghambat Implementasi Peraturan Daerah No. 2 Tahun 2006 tentang Peanggulangan Hewan Beresiko Rabies khususnya hewan anjing di Kabupaten Minahasa Tenggara. Adapun metode yang digunakan yaitu metode penelitian kualitatif. Dimana hasilnya diketahui berdasarkan indikator pencegahan rabies, pemeliharaan dan peran serta masyarakat sudah berjalan melalui peran pemerintah dinas peternakan dan pertanian kabupaten minahasa tenggara dimana melakukan pendataan, vaksinasi dan penangkaran hewan liar. Walaupun memang belum berjalan dengan masksimal dimana masih terdapatnya kasus pembiaran hewan peliharaan beresiko rabies. Pelaksanaan Implementasi Peraturan Daerah Nomor 2 Tahun 2016 tentang Penanggulangan Hewan Beresiko Rabies khususnya hewan anjing di Kabupaten Minahasa Tenggara belum berjalan sebagaimana mestinya sehingga kebijakan ini dinilai belum tepat. Faktor-faktor penghambat dan pendukung Implementasi Peraturan Daerah Nomor 2 Tahun 2016 tentang Penanggulangan Hewan Beresiko Rabies khususnya hewan anjing di Kabupaten Minahasa Tenggara disebabkan oleh kesadaran dari masyarakat yang masih kurang serta tidak adanya pendampingan dalam proses pencegahan.

Kata kunci: Model Grindle, Model Mazmanian dan Sabatier, Peraturan
Daerah, Hewan Beresiko Rabies, Minahasa Tenggara

\section{PENDAHULUAN}

Banyak penduduk yang memiliki kebiasaan serta kegemaran memelihara hewan berkaki empat termasuk anjing, sebab dari sekian banyak Hewan Pembawa Rabies (HPR), anjing adalah yang paling sering menjadi sumber penularannya.

Rabies sendiri adalah penyakit menular yang bersifat akut, menyerang susunan syaraf pusat yang dapat menulari semua hewan berdarah panas dan manusia yang disebabkan oleh virus rabdoviridae. Motifasi untuk memelihara hewan anjing tersebut juga beragam. Ada yang hanya sekedar hoby, sebagai penjaga rumah tapi juga untuk dikomsumsi, apalagi jika merujuk pada kultur budaya orang Minahasa yang Secara komersil turut mempengaruhi pasaran hewan anjing yang semakin naik, Belum lagi letak dan kondisi Kabupaten Minahasa Tenggara yang berada di antara beberapa kabupaten lain yang ada di Provinsi Sulawesi Utara, seperti Minahasa, Minahasa Selatan dan Bolaang Mongondow Timur Kondisi tersebut membuat peredaran hewan anjing antar daerah terutama hewan yang masuk, tak bisa dibendung dan dideteksi. Hal ini turut mempengaruhi populasi anjing di Kabupaten Minahasa Tenggara. Tapi pertumbuhan hewan tesebut justru tidak diiringi dengan kesadaran masyarakat untuk memelihara secara sehat dan aman.

Menurut data yang ada dari Pemerintah Kabupaten Minahasa Tenggara lewat instansi teknis Dinas Pertanian dan Dinas Kesehatan menyangkut kasus gigitan anjing 
dan korban positif rabies sehingga peristiwa tersebut dianggap Kejadian Luar Biasa (KLB), dapat dilihat dalam tabel di bawah ini:

Tabel 1.1 Kasus Gigitan Anjing

\begin{tabular}{ccccc}
\hline $\begin{array}{c}\text { N } \\
\mathbf{0}\end{array}$ & $\begin{array}{c}\text { Tahu } \\
\mathbf{n}\end{array}$ & $\begin{array}{c}\text { Kasus } \\
\text { Gigita } \\
\mathbf{n}\end{array}$ & $\begin{array}{c}\text { Positi } \\
\mathbf{f} \\
\text { Rabie } \\
\text { s }\end{array}$ & $\begin{array}{c}\text { Meningg } \\
\text { al }\end{array}$ \\
\hline 1. & 2013 & 386 & 7 & 7 \\
\hline 2. & 2014 & 282 & 2 & 2 \\
\hline 3. & 2015 & 303 & 1 & 1 \\
\hline 4. & 2016 & 224 & 1 & 1 \\
\hline
\end{tabular}

Hal ini yang menjadi indikator utama ditetapkannya Peraturan Daerah Nomor 2 tahun 2016 tentang Penanggulangan Hewan Beresiko rabies yang juga menjadi produk Peraturan Daerah pertama di Provinsi Sulawesi Utara yang bertujuan untuk membebaskan Minahasa Tenggara dari Rabies.

Masalah yang harus diatasi oleh pemerintah adalah masalah publik yaitu nilai, kebutuhan atau peluang yang tak terwujudkan. Meskipun masalah tersebut dapat diidentifikasi tapi hanya mungkin dicapai lewat tindakan publik yaitu melalui kebijakan publik [1].

Sejak dikeluarkannya Peraturan Daerah No. 2 tahun 2016 Pemerintah Kabupaten Minahasa Tenggara lewat instansi teknis dalam hal ini Dinas Pertanian telah melakukan implementasi / penerapan dalam bentuk Sosilisasi kepada masyarakat, dengan melibatkan stakeholder yang ada terutama peran para Camat dan Hukum Tua. Hal penting yang sering disampaikan agar para pemilik hewan beresiko rabies (anjing) dapat memahami cara penanganan dan pemeliharaannya terutama bahwa hewan tersebut harus divaksin 6 bulan sekali dan diikat atau dikandangkan [2].

Tahun 2018 telah beberapa kali dilakukan upaya penindakan, penertiban dan eliminasi / penangkapan bagi hewan penular Rabies (anjing) dengan melibatkan pihak Kepolisian, Satuan Polisi Pamong praja di beberapa desa dan kecamatan namun kesadaran masyarakat belum terbangun secara maksimal. Pengamatan kami dilapangan ternyata masih banyak lagi desa-desa, terutama bagi masyarakat pemilik anjing yang belum mengindahkan regulasi yang ada tentang penanganan hewan beresiko rabies. Masih banyak lagi anjing-anjing yang berkeliaran bebas, yang tidak diikat atau dikandangkan bahkan dalam jadwal vaksinasi, ketika para vaksinator turun ke desa -desa, ada masyarakat yang enggan anjingnya di vaksin, atau tidak berada di tempat. Hal ini juga menunjukkan peran para aparat / pemerintah desa belum maksimal. Dari permasalahan ini menunjukkan bahwa untuk menciptakan Kabupaten Minahasa Tenggara bebas rabies masih perlu proses dan penanganan lebih serius dari seluruh stakeholder yang ada, walaupun harus diakui telah terjadi penurunan drastis terutama untuk korban posistif rabies.

Hal ini tentu menjadi fokus kajian yang menarik untuk diteliti karena juga melibatkan semua stakeholder terkait. Karena itu sebagai peneliti, saya mengangkat judul "Impementasi Peraturan Daerah No. 2 tentang Penanggulangan Hewan Beresiko Rabies di Kabupaten Minahasa Tenggara".

\section{Rumusan Masalah}

Bertitik tolak pada latar belakang dan fokus penelitian tersebut maka rumusan masalah pada penelitian sebagai berikut :

1. Bagaimakah Implementasi PERDA No 2 Tahun 2016 tentang Penanggulangan Hewan Beresiko Rabies khususnya hewan anjing di Kabupaten Minahasa Tenggara?

2. Faktor-faktor apa sajakah yang menjadi penghambat Implementasi PERDA No. 2 Tahun 2016 tentang Penanggulangan 
Hewan Beresiko Rabies di Kabupaten Minahasa Tenggara.

\section{TUJUAN PENELITIAN}

1. Implementasi Peraturan Daerah No.2 Tahun 2016 tentang Penanggulangan Hewan Beresiko Rabies khususnya hewan anjing di Kabupaten Minahasa Tenggara

2. Faktor-faktor penghambatImplementasi Peraturan Daerah No. 2 Tahun 2006 tentang Peanggulangan Hewan Beresiko Rabies khususnya hewan anjing di Kabupaten Minahasa Tenggara

\section{METODE PENELITIAN}

Penelitian ini adalah menggunakan jenis Penelitian Kualitatif dengan analisis Deskriptif. Metode penelitian kualitatif adalah metode penelitian yang digunakan untuk meneliti pada kondisi objek yang alamiah, dimana peneliti adalah instrumen kunci, dengan teknik pengambilan data dilakukan secara triangulasi (gabungan), analisis data bersifat induktif dan hasil penelitian kualitatif lebih menekankan pada makna dari pada generalisasi.

Melalui metode penelitian kualitatif ini peneliti berharap mampu mengungkapkan berbagai pertimbangan yang dipakai oleh policy makers dalam menetapkan kebijakan PERDA Nomor 2 Tahun 2016 tentang Penanggulangan Hewan beresiko Rabies di Kabupaten Minahasa Tenggara sehingga akhirnya mampu mendiskripsikan bagaimana proses pengimplementasian kebijakan tersebut [3].

\section{Fokus Penelitian}

Fokus utama penelitian ini didasarkan pada tujuan, sasaran kebijakan Peraturan Daerah Kabupaten Minahasa Tenggara No. 2 Tahun 2016 tentang penanggulangan hewan beresiko rabies baik dilihat dari implementasi maupun determinan. Adapun Indikator yang menjadi fokus penelitian dalam implementasi PERDA No. 2 Tahun 2016 adalah :

- $\quad$ Pencegahan Rabies, Bab III pasal 3

- Pemeliharaan, Bab IV pasal 5

- Peran serta masyarakat, Bab VIII pasal 17

\section{HASIL \& PEMBAHASAN}

1. Implementasi Peraturan Daerah No. 2 Tahun 2016 tentang Penanggulangan Hewan Beresiko Rabies khususnya hewan anjing di Kabupaten Minahasa Tenggara.

Adapun yang menjadi temuan peneliti untuk mengetahui bagaimana implementasi peraturan daerah No. 2 Tahun 2016 tentang penanggulangan hewan beresiko rabies khususnya hewan anjing pada indikator Pencegahan, Pemeliharaan, dan Peran Serta Masyarakat.

a. Pencegahan

Dalam upaya pencegahan dan penanggulangan rabies di Kabupaten Minahasa Tenggara, pemerintah, dalam hal ini Dinas Pertanian sebagaimana pengamatan dan hasil wawancara dengan beberapa narasumber bahwa sosialisasi Perda No.2 Tahun 2016 telah dilakukan dengan melibatkan stakeholder yang ada sampai ke tingkat desa dan kelurahan terutama peran Camat dan Hukum Tua. Tapi sayangnya upaya sosialisasi ini tidak berjalan secara kontinyu. Kegiatan vaksinasi juga terus dilakukan oleh para vaksinator di dinas terkait di semua desa dan kelurahan dalam enam (6) bulan sekali. Diakui oleh dinas terkait dengan wilayah yang luas dan dengan populasi dan penyebaran hewan anjing justru tidak sebanding dengan tenaga vaksinator yang ada, yang masih 
sangat kurang. Belum lagi berhadapan dengan tingkat kesadaran masyarakat masih rendah untuk memberi anjingnya divaksin. Bahkan ada yang dengan sengaja membawa dan melarikan anjingnya kekebun karena takut anjingnya kena penyakit pasca divaksin.

b. Pemeliharaan

Pola dan gaya pemeliharaan sesuai amanat Perda No. 2 tahun 2016 pada Bab IV pasa 5 terutama bahwa HPR atau hewan penular rabies anjing seharusnya diikat atau dikandangkan. Tapi temuan lewat beberapa sumber ternyata banyak masyarakat yang sengaja membiarkan anjingnya berkeliaran bebas tanpa diikat atau dikandangkan walaupun sosialisasi dari pemerintah lewat dinas Pertanian ataupun para Camat dan Hukum Tua telah dilakukan. Dalam Implementasi Perda Nomor 2 tahun 2016 pemerintah dalam hal ini Dinas Pertanian telah melakukan sekali upaya penindakan dan penangkapan hewan anjing yang berkeliaran bebas bekerja sama dengan pihak POLRI, SatPol PP dan pemerintah Kecamatan dan desa tapi juga menurut sumber karena keterbatasan anggaran tidak dapat menjangkau semua kecamatan dan desa akibat keterbatasan anggaran.

c. Peran Serta Masyarakat

Hasil wawancara dari beberapa sumber, peneliti menemukan beberapa hal yang menggambarkan bagaimana pelakasanaan kebijakan dalam Perda No. 2 tahun 2016 ternyata masih ada masyarakat tidak tahu tentang penanggulangan hewan beresiko rabies dikarenakan pemerintah belum melakukan sosialisasi secara menyeluruh dan terus menerus tentang penanggulangan hewan beresiko rabies menyebabkan keterlibatan masyarakat. Penulis melihat, selain peran pemangku kepentingan yang tidak berjalan baik tapi juga peran serta masyarakat yang belum maksimal. Salah satu factor yang mempengaruhinya adalah sumber daya.

\section{KESIMPULAN}

Berdasarkan hasil data penelitian yang telah di analisis dan pembahasan hasil peneltian yang sudah diuraikan pada bab sebelumnya. Maka terdapat beberapa kesimpulan:

A. Pelaksanaan Implementasi Peraturan Daerah Nomor 2 Tahun 2016 tentang Penanggulangan Hewan Beresiko Rabies khususnya hewan anjing di Kabupaten Minahasa Tenggara belum berjalan sebagaimana mestinya.

B. Faktor-faktor penghambat dan pendukung Implementasi Peraturan Daerah Nomor 2 Tahun 2016 tentang Penanggulangan Hewan Beresiko Rabies khususnya hewan anjing di Kabupaten Minahasa Tenggara disebabkan belum maksimalnya sistim tingkatan birokrasi dalam memberikan sosialisasi tapi juga kesadaran dari masyarakat yang masih kurang.

\section{REFERENSI}

[1] Nugroho Riant, 2008. Public Policy. Jakarta: PT Elex Media Komputindo

[2] Peraturan Daerah No. 2 tahun 2016 Pemerintah Kabupaten Minahasa Tenggara 
Jurnal Kajian Kebijakan dan Ilmu Administrasi Negara (JURNAL ADMINISTRO)

Vol 2 No. 22020 P ISSN: 2714 -6413 E ISSN: $2714-6421$

http://ejournal.unima.ac.id/index.php/administro

[3] PERDA Nomor 2 Tahun 2016 tentang Penanggulangan Hewan beresiko Rabies di Kabupaten

[5] Dunn, William N. 2003. Analisis Minahasa Tenggara

Kebijakan Publik. Yogyakarta : Gadjah Mada University Press.

[4] Peraturan Daerah No. 2 Tahun 2016 tentang penanggulangan hewan beresiko rabies 